Article

\title{
The Effect of Light on Antioxidant Properties and Metabolic Profile of Chia Microgreens
}

\author{
Selma Mlinarić ${ }^{1}$ [D, Vlatka Gvozdić $^{2}$, Ana Vuković ${ }^{1}$, Martina Varga ${ }^{1}$, Ivan Vlašiček ${ }^{1}$, \\ Vera Cesar $^{1}$ and Lidija Begović ${ }^{1, * \mathbb{C}}$ \\ 1 Department of Biology, J. J. Strossmayer University of Osijek, Ulica cara Hadrijana 8/A, 31000 Osijek, Croatia; \\ smlinaric@biologija.unios.hr (S.M.); avukovic@biologija.unios.hr (A.V.); mjelosek@biologija.unios.hr (M.V.); \\ ivan.vlasicek@gmail.com (I.V.); vcesarus@yahoo.com (V.C.) \\ 2 Department of Chemistry, J. J. Strossmayer University of Osijek, Ulica cara Hadrijana 8/A, 31000 Osijek, \\ Croatia; vgvozdic@kemija.unios.hr \\ * Correspondence: lbegovic@biologija.unios.hr; Tel.: +385-31-399-936
}

Received: 30 July 2020; Accepted: 17 August 2020; Published: 19 August 2020

check for updates

Featured Application: Exposition of dark-grown chia microgreens to lower light intensity increases the production of bioactive compounds and enhances their antioxidative activity. Therefore, illuminated chia microgreens have the potential to be included in human diet as well as raw seeds.

\begin{abstract}
Chia (Salvia hispanica L.) is a one-year plant known as a source of nutrients that can be consumed in the diet in the form of seeds or sprouts. The purpose of this study is to investigate the effect of illumination for 24 and $48 \mathrm{~h}$ on dark-grown chia microgreens. Total antioxidant capacity was measured using 2,2-diphenyl-1-picrylhydrazyl (DPPH) and ferric-reducing antioxidant power (FRAP) assays, along with the total phenolics, ascorbic acid and cellulose content, and chlorophyll and carotenoid concentrations. Fourier transform infrared spectroscopy (FTIR) was used to evaluate the biochemical composition and elucidate the changes in compound structures between dark-grown and illuminated chia microgreens. Analysis of the results showed that illumination significantly increased the content of all measured bioactive compounds as well as antioxidative capacity, especially $48 \mathrm{~h}$ after exposure to light. FTIR analyses supported structural and molecular changes in chia microgreens grown under different light regimes. Our results suggest that illumination has a positive effect on the antioxidant potential of chia microgreens, which may present a valuable addition to the human diet.
\end{abstract}

Keywords: Salvia hispanica; antioxidant activity; DPPH; polyphenolics; ascorbic; acid; carotenoids; light

\section{Introduction}

Chia (Salvia hispanica L.) is a one-year-old plant (Lamiaceae) that is a native species in Mexico and Northern Guatemala, where it was bred as a cereal in pre-Columbian times. An adult plant grows up to $1 \mathrm{~m}$ in height and has versatile leaves that are $5 \mathrm{~cm}$ wide and $8 \mathrm{~cm}$ long, with white to purple flowers. The most important product of this plant is its seeds, which are 1-2 mm in diameter, oval, black, gray, or white, with black dots [1]. The seeds are used whole or in the form of flour or oil. Although they have a neutral taste, they are an interesting addition to diet because they form a sticky mucus in contact with water [2,3]. Whole seeds and sprouts are added to salads and beverages to improve the density, and for the same reason, flour can be added to yogurt. The cultivation of chia sprouts is very simple, and they have also been recently used in the human diet for their nutritive and antioxidative properties $[4,5]$. 
Sprouts or microgreens are grown from the seeds of various kinds of grains, vegetables, nuts, and legumes. They have a high content of protein, calcium, magnesium, vitamin A, vitamin B, ascorbic acid, and vitamin E [6,7]. The use of microgreens is increasingly popular and they are considered the food of the future due to their relatively light weight, fast and easy growing, and high nutritional value [6].

Light intensity, quality, and duration significantly influence plant growth and development through morphogenesis, the functioning of the photosynthetic apparatus, and metabolic pathways [8]. Light conditions also have the potential to evoke different actions of the antioxidant system [9] and metabolic pathways $[10,11]$. Light can enhance the synthesis of different antioxidants such as ascorbic acid [11,12], polyphenols, carotenoids, chlorophylls, and other enzymatic and nonenzymatic compounds that help in preventing and balancing oxidative damages in plants [13]. However, different growth conditions can have an impact on the antioxidative and nutritive properties of plant species [6].

Sprouts used in diets are usually grown in dark conditions and consumed raw. They show a pale yellow color due to the lack of chlorophyll. After exposure to light, the expression of genes involved in chlorophyll and carotenoid biosynthesis is upregulated, leading to the change of color from pale yellow to green $[14,15]$. Different sprouts or microgreens are considered to be young plants of vegetables, grains, and herbs, with two fully developed cotyledons. Due to their antioxidant capacity and various bioactive compounds with antibacterial, anti-inflammatory, and other health beneficial properties, sprouts are considered "functional food" [16], which has recently been widely grown and used in the global food system.

Fourier transform infrared spectroscopy (FTIR) is widely used for the identification of biomolecules, functional groups, types of bonding, and changes in molecular conformations. Due to its extensive applicability to the different kinds of tissues and a small amount of sample needed for analyses, this technique has found broad applications in the analyses of metabolic profiles of different plant species [17]. FTIR spectroscopy is used for the determination of antioxidant potential and health benefits in chia [18-20], as well as other medicinal plants [17].

Although there have been many reports on the connection between the effect of light on nutritive properties and the antioxidant capacity of various microgreens, few studies have investigated the effect of light on nutritional properties and bioactive compounds in chia microgreens under different light regimes. Therefore, the aim of this work is to determine the effect of illumination on dark-grown chia microgreens by measuring total antioxidant capacity, the concentration of carotenoids and chlorophylls, total soluble phenolics, and ascorbic acid and cellulose content, as well changes in biochemical composition and structure of biomolecules by Fourier transform infrared spectroscopy (FTIR).

\section{Materials and Methods}

\subsection{Plant Material and Light Treatment}

Chia seeds (Salvia hispanica L., producer Golden Sun, Trittau, Germany) were planted on two layers of moistened filter paper in glass jars $(400 \mathrm{~mL})$. In each jar, $1.5 \mathrm{~g}$ of seeds were planted. The jars were then wrapped in aluminum foil and perforated on the top to allow ventilation during growth. The jars were placed in a growth chamber at $22 \pm 1{ }^{\circ} \mathrm{C}$. Plants were grown for seven days and watered every other day. Afterward, microgreens were exposed to constant light $\left(100 \mu \mathrm{mol}\right.$ photons $\left.\mathrm{m}^{-2} \mathrm{~s}^{-1}\right)$ for 24 and $48 \mathrm{~h}$, and the dark-etiolated plants were considered as control. Three biological replicates (each group contained $1.5 \mathrm{~g}$ of seeds) of samples with three light treatments were collected and used for analyses. Etiolated microgreens were additionally protected from light by placing them in the cardboard box. 


\subsection{Determination of Chlorophyll and Carotenoid Content}

One hundred milligrams of fresh seedling tissue were ground in liquid nitrogen using mortar and pestle. The extraction of pigments was performed in pure acetone for $24 \mathrm{~h}$ at $-20^{\circ} \mathrm{C}$. Next day samples were centrifuged at $18,000 \times g$ for $10 \mathrm{~min}$ at $4{ }^{\circ} \mathrm{C}$. The absorbance was measured at 470,645 , and $662 \mathrm{~nm}$ using a spectrophotometer (Specord 40, Analytik Jena, Jena, Germany), and pure acetone was used as a blank. Carotenoid and chlorophyll content were determined according to Lichtenthaler [21].

\subsection{Total Soluble Polyphenols and Protein Content}

Approximately $500 \mathrm{mg}$ of fresh seedling tissue was used for analyses. Plant material was ground in liquid nitrogen and extracted for $24 \mathrm{~h}$ at $-20^{\circ} \mathrm{C}$ in $2.5 \mathrm{~mL}$ of $96 \%$ ethanol [6]. Measurement of total soluble polyphenol content was performed in the reaction mixture containing $100 \mu \mathrm{L}$ of ethanol extract, $700 \mu \mathrm{L}$ of distilled $\mathrm{H}_{2} \mathrm{O}, 50 \mu \mathrm{L}$ of Folin-Ciocalteu reagent, and $150 \mu \mathrm{L}$ of sodium carbonate solution $(200 \mathrm{~g} / \mathrm{L})$. Samples were incubated in a water bath for $60 \mathrm{~min}$ and $37^{\circ} \mathrm{C}$, and absorbance was measured spectrophotometrically at $765 \mathrm{~nm}$ using gallic acid (GA) as a standard. Total polyphenol content was expressed as gallic acid equivalents per $\mathrm{g}$ of fresh weight (FW).

Protein content was determined using the Bradford assay [22]. Briefly, $500 \mathrm{mg}$ of ground tissue was extracted with $1 \mathrm{~mL}$ of $100 \mathrm{mM} \mathrm{KP}$ buffer, $\mathrm{pH}=7.0$. After $15 \mathrm{~min}$ of extraction on ice, samples were centrifuged at $18,000 \times g$ for $15 \mathrm{~min}$ and $4{ }^{\circ} \mathrm{C}$. Supernatants were used for protein content determination. Absorbance was measured spectrophotometrically using $1 \mathrm{mg} / \mathrm{mL}$ of bovine serum albumin (BSA) as a standard. Protein content was expressed as mg per g of fresh weight (FW).

\subsection{Estimation of Total Antioxidant Capacity}

\subsubsection{DPPH Scavenging Activity}

DPPH scavenging activity was determined according to the Brand-Williams method [23], using the same extract for the determination of total soluble phenolic content. The reaction mixture contained $20 \mu \mathrm{L}$ of extract and $980 \mu \mathrm{L}$ of $0.094 \mathrm{mM}$ DPPH (2,2-diphenyl-1-picrylhydrazyl) previously dissolved in methanol. The reaction was carried out in the dark at $22{ }^{\circ} \mathrm{C}$ for $15 \mathrm{~min}$, with occasional shaking. The standard curve was prepared by dissolving $2.5 \mathrm{mg}$ of Trolox (6-hydroxy-2,5,7,8-tetramethylchroman-2-carboxylic acid) in $10 \mathrm{~mL}$ of methanol. Absorbance was measured at $515 \mathrm{~nm}$. Total antioxidant activity was expressed as the equivalents of Trolox per $\mathrm{g}$ of fresh weight (FW).

\subsubsection{Ferric Reducing Antioxidant Power Assay (FRAP)}

Frozen tissue powder $(200 \mathrm{mg}$ ) was extracted on ice with the addition of cold $80 \% \mathrm{EtOH}$ for $15 \mathrm{~min}$. After the extraction, samples were placed in a hot bath at $84^{\circ} \mathrm{C}$ for $30 \mathrm{~min}$. The homogenate was centrifuged at $22,000 \times g$ and $4{ }^{\circ} \mathrm{C}$ for $15 \mathrm{~min}$. The supernatant was used for further analyses of antioxidant capacity by FRAP. The FRAP assay is based on antioxidants as electron-donors in reaction with a yellow ferric 2,4,6-tripyridyl-s-triazine (Fe III TPTZ) complex, resulting in a blue-colored ferrous form (Fe II TPTZ). The intensity of the blue color, which is proportional to the reducing power of the antioxidants, was monitored spectrophotometrically at $593 \mathrm{~nm}$. The reaction mixture for the FRAP assay consisted of $0.5 \mathrm{mM} \mathrm{TPTZ}$ and $1 \mathrm{mM} \mathrm{FeCl}_{3} \cdot 6 \mathrm{H}_{2} \mathrm{O}$ in acetate buffer $(\mathrm{pH}$ 3.6). The sample $(10 \mu \mathrm{L})$ and reaction mixture $(290 \mu \mathrm{L})$ were added to the wells of microtiter plates, mixed, and incubated at room temperature. After incubation, absorbance at $593 \mathrm{~nm}$ was measured using a microplate reader (Tecan, Spark, Männedorf, Switzerland). Total antioxidant capacity was determined using a standard curve in which Trolox was used as a standard at a concentration range from 0.25 to $2 \mathrm{mM}$. The results are expressed in $\mu \mathrm{mol}$ Trolox equivalents per $100 \mathrm{~g}$ of fresh weight (FW). 


\subsection{Ascorbic Acid Content}

Approximately $600 \mathrm{mg}$ of fresh tissue was ground with mortar and pestle in liquid nitrogen and extracted in $10 \mathrm{~mL}$ of distilled water. The homogenates were centrifuged for $15 \mathrm{~min}$ at $3000 \times \mathrm{g}$ at $4{ }^{\circ} \mathrm{C}$. The supernatant was used for the determination of ascorbic acid content [24]. The reaction mixture consisted of $300 \mu \mathrm{L}$ of aqueous extract, $100 \mu \mathrm{L}$ of $13.3 \%$ trichloroacetic acid, $25 \mu \mathrm{L}$ of deionized water, and $75 \mu \mathrm{L}$ of 2,4-dinitrophenylhydrazine (DNPH) reagent. The DNPH reagent was prepared by dissolving $2 \mathrm{~g}$ of DNPH, $230 \mathrm{mg}$ of thiourea, and $270 \mathrm{mg}$ of $\mathrm{CuSO}_{4}$ in $100 \mathrm{~mL}$ of $5 \mathrm{M} \mathrm{H}_{2} \mathrm{SO}_{4}$. Blanks were made in parallel for each sample, as described above, without the addition of the DNPH reagent. Samples were incubated in a water bath for $60 \mathrm{~min}$ at $37^{\circ} \mathrm{C}$. After incubation, the DNPH reagent was added to all blanks, and $500 \mu \mathrm{L}$ of $65 \% \mathrm{H}_{2} \mathrm{SO}_{4}$ was added to all samples. The absorbance was measured at $520 \mathrm{~nm}$. The concentration of ascorbic acid was obtained from a standard curve with known concentrations of ascorbic acid $(2.5-20 \mu \mathrm{g} / \mathrm{mL})$. The content of ascorbic acid is expressed in $\mathrm{mg}$ per $100 \mathrm{~g}$ of fresh weight.

\subsection{Determination of Crystalline Cellulose Content}

Chia microgreens were dried at $65^{\circ} \mathrm{C}$ for $48 \mathrm{~h}$, ground with mortar and pestle, and extracted four times at $80^{\circ} \mathrm{C}$ using $80 \%$ ethanol. Crystalline cellulose content was determined according to Foster et al. (2010) using Updegraff reagent [25]. One mL of Updegraff reagent (acetic acid: nitric acid: water, 8:1:2 v/v) was added to the $70 \mathrm{mg}$ of dry tissue. Afterward, samples were heated at $100^{\circ} \mathrm{C}$ for $30 \mathrm{~min}$, centrifuged, and the pellet was washed with water and acetone and air-dried overnight. The pellet was hydrolyzed with $72 \%$ sulfuric acid. Crystalline cellulose content was determined using the colorimetric Anthrone assay for 96-well microtiter plates [26]. For standard curve preparation, glucose $(1 \mathrm{mg} / \mathrm{mL})$ and Anthrone reagent $(2 \mathrm{mg} / \mathrm{mL}$ sulfuric acid) were used. Crystalline cellulose content was measured using a microplate reader (Tecan, Spark, Männedorf, Switzerland) and expressed as glucose equivalents.

\subsection{Fourier Transform Infrared Spectroscopy (FTIR)}

FTIR was used to screen the dark-grown and illuminated chia seedlings. After grinding, $3 \mathrm{mg}$ of dry tissue sample was mixed with $100 \mathrm{mg}$ of $\mathrm{KBr}$ (spectroscopy grade, Merck, Darmstat, Germany). Each FTIR spectrum was recorded by 20 co-added scans at a resolution of $2 \mathrm{~cm}^{-1}$ in the region of wave number (WN) 500 to $4000 \mathrm{~cm}^{-1}$ (FTIR-8400S, Shimadzu, Tokyo, Japan). The spectra were baseline-corrected.

\subsection{Statistical Analyses}

The mean values between the different groups (dark-grown, $24 \mathrm{~h}$, and $48 \mathrm{~h}$ ) were subjected to analyses of variance one-way ANOVA. Subsequently, a posthoc analysis was performed using Fisher's LSD test (the least significant difference). The experiment was repeated three times, with five technical replicates. The results are presented as mean \pm standard deviation (SD) of 15 replicates. The analyses were performed with Statistica 13.1. (Tibco Software Inc., Palo Alto, CA, USA).

\section{Results and Discussion}

\subsection{Effect of Illumination on Carotenoid and Chlorophyll Content}

Dark-grown chia microgreens showed an etiolated, pale phenotype with increased hypocotyl length. After exposure of the etiolated chia microgreens to light, a change of color from pale to green was evident after $24 \mathrm{~h}$, indicating the beginning of chlorophyll synthesis and subsequent development of the photosynthetic apparatus. Similar findings were also reported by Paiva et al. [27], where the authors investigated chia germination and seedling development under different light regimes. These authors 
found that when chia was germinated under constant-dark conditions, seedlings had the longest shoots, while under constant-light, the shoots were shorter.

The concentrations of total chlorophyll and carotenoid content differed significantly between dark-grown microgreens and microgreens exposed to light (Figure 1). Compared to dark-grown microgreens, the increase was observable $24 \mathrm{~h}$ after the treatment. Additionally, there was an evident increase in the concentration of both total chlorophyll (Figure 1a) and carotenoid content (Figure 1b) in chia microgreens $48 \mathrm{~h}$ after the treatment.

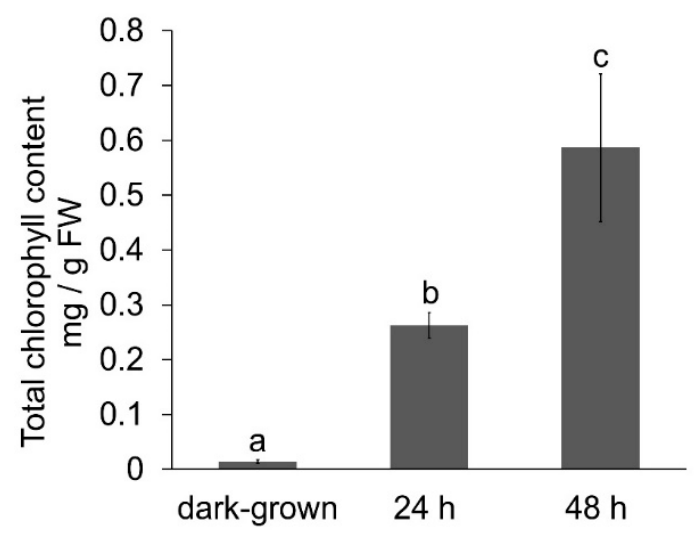

(a)

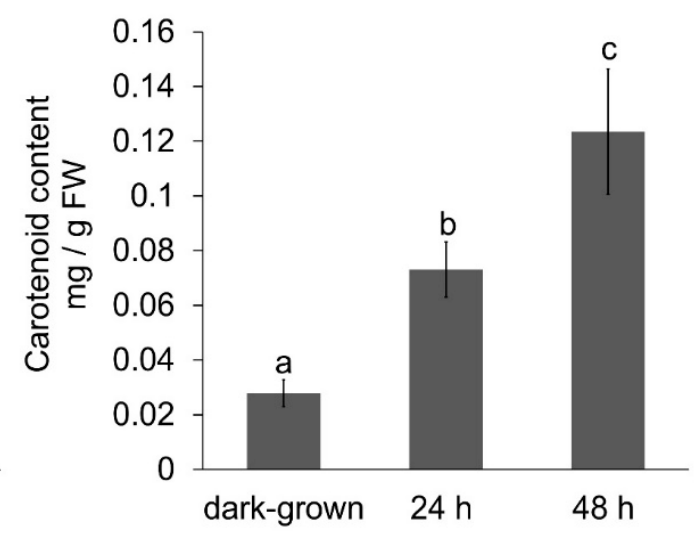

(b)

Figure 1. Total chlorophyll (a) and carotenoid (b) content in dark-grown chia microgreens and microgreens after exposure to light for 24 and $48 \mathrm{~h}$. Data represent mean values from three experiments with five replicates $(n=15)$. The error bars show standard deviation (SD). Different letters signify values that are statistically different at $p \leq 0.05$ according to Fisher's LSD test.

The increase of photosynthetic pigments in treated chia microgreens indicates the association between chlorophyll and carotenoid synthesis and the length of exposure to light.

As reviewed in Solymosi and Mysliwa-Kurdziel [28], chlorophylls are good antioxidants because of their effective scavenging activity of reactive oxygen species (ROS) and inhibition of lipid peroxidation. Chlorophylls are most commonly used as natural food colorants, but, recently, their bioactive properties [29] have become more in focus as research has shown their emerging role as potential prebiotics in rebalancing gut microbiota in mice [30].

Dietary intake of carotenoids is associated with a reduced risk of degenerative diseases [31,32] and stroke prevention [33], and this suggests their anti/pro-oxidant roles [34]. In our study, light caused an increase of carotenoid content in chia seedlings and therefore increased their antioxidative properties. Lower light intensity in a range from 100 to $300 \mu \mathrm{mol} \mathrm{m}{ }^{-2} \mathrm{~s}^{-1}$ had a positive effect on photosynthetic processes [35], increased chlorophyll content [36], and more effective light use [37] in plants. In this study, we used the light intensity of $100 \mu \mathrm{mol}$ photons $\mathrm{m}^{-2} \mathrm{~s}^{-1}$, which generally has a beneficiary effect on the synthesis of different investigated bioactive compounds and enhances antioxidative properties in chia microgreens.

\subsection{Effect of Illumination Total Phenolic and Protein Content}

The content of total phenolics increased after the illumination with respect to the dark-grown chia microgreens. The analysis did not show the differences between chia microgreens after exposure to light for $24 \mathrm{~h}$ and $48 \mathrm{~h}$ (Figure 2). 


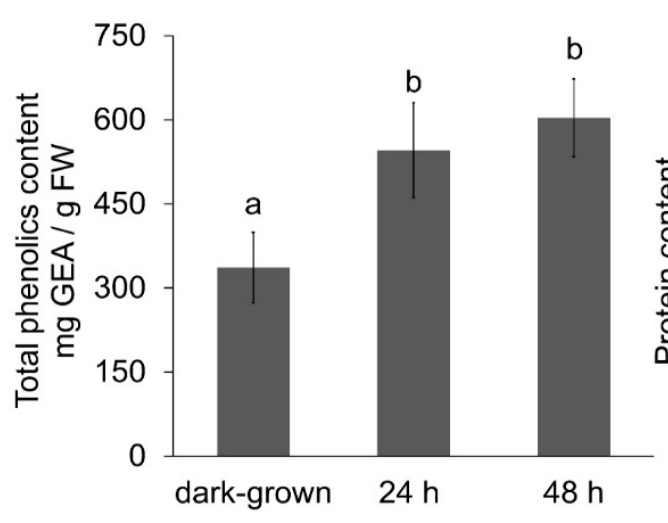

(a)

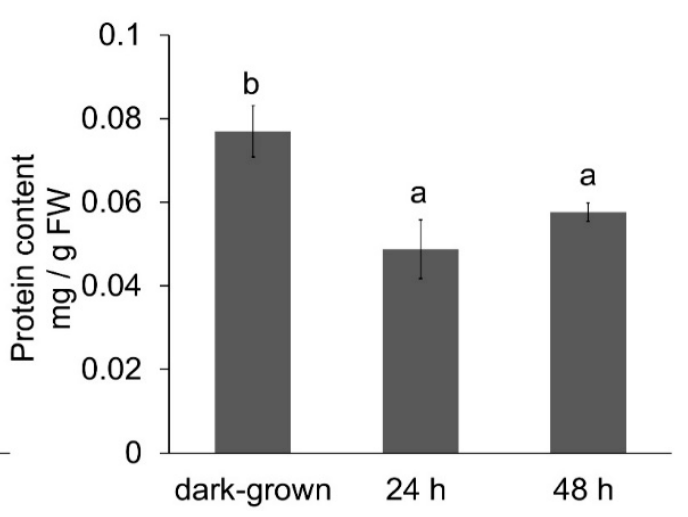

(b)

Figure 2. Total phenolic content (a) and protein content (b) in dark-grown chia microgreens and microgreens after exposure to light for 24 and $48 \mathrm{~h}$. Data represent mean values from three experiments with five replicates $(n=15)$. The error bars show standard deviation (SD). Different letters signify values that are statistically different at $p \leq 0.05$ according to Fisher's LSD test.

Different soluble phenolic content reported in numerous studies have shown that the mechanisms of polyphenol synthesis vary between plant species, raw seeds, and sprouts, and is also affected by different growth conditions, germination processes, and sprout developmental stages [7]. Gómez-Favela et al. [5] showed that the controlled germination process exhibited a higher content of bioactive compounds (among others, increased total phenolics) in flour from chia seeds. Compared with the content of phenolics in other sprouts, our results showed that the amount of phenolics in illuminated chia microgreens ( 24 and $48 \mathrm{~h}$ ) was higher or similar [7,38,39]. These variations could be attributed to the different enzymatic activity of hydrolases and polyphenol oxidases [40], de novo synthesis of phenolics, differences in polymerization and oxidation processes, and degradation of free or bound phenolics [41,42]. The increase of phenolics observed after exposure to light could also be attributed to the development of defense mechanisms as a response to illumination, which activates different metabolic pathways to enhance antioxidant activity in etiolated sprouts. Therefore, illuminated chia microgreens represent a significant source of phenolics and can be considered as an alternative source in diets.

Under constant-dark conditions, protein content was significantly higher when dark-grown chia microgreens and illuminated microgreens were compared (Figure 2b). Additionally, protein content did not differ between chia microgreens 24 and $48 \mathrm{~h}$ after the light treatment. Proteins represent storage for germinating seeds, and, during the germination process, they are hydrolyzed by proteases, which increases their availability for plant growth [6]. The soluble protein content, however, also depends on the balance between synthesis and demand [6]. In a recent work by Mastropasqua et al. [43], authors showed that exposure to light impacted protein synthesis in soybean, mung bean, pumpkin, and radish sprouts differently. Namely, dark-grown mung bean sprouts had significantly higher soluble protein content in comparison to corresponding sprouts exposed to light, which is in accordance with our results. This decreased protein content in chia microgreens after light treatment could be explained by the increased degradation of proteins due to higher demand for developmental processes taking part in growing microgreens induced by light and redirecting metabolic pathways towards the synthesis of other secondary metabolites and components involved in photoprotection.

\subsection{Effect of Illumination on Ascorbic Acid Content}

Ascorbic acid (AA) is involved in numerous functions in plants, from antioxidative defense and photosynthesis to growth regulation [44]. Light triggers seed germination and influences the 
biosynthesis of ascorbic acid [45]. Higher irradiance levels can increase the content and accumulation of AA in plants [12].

Ascorbic acid (AA) content significantly varied between dark-grown and illuminated chia microgreens (Figure 3). It is clearly visible that the length of illumination is associated with increasing the content of AA. Analysis of the results showed that there were statistically significant differences $(p \leq 0.05)$ between all three chia samples.

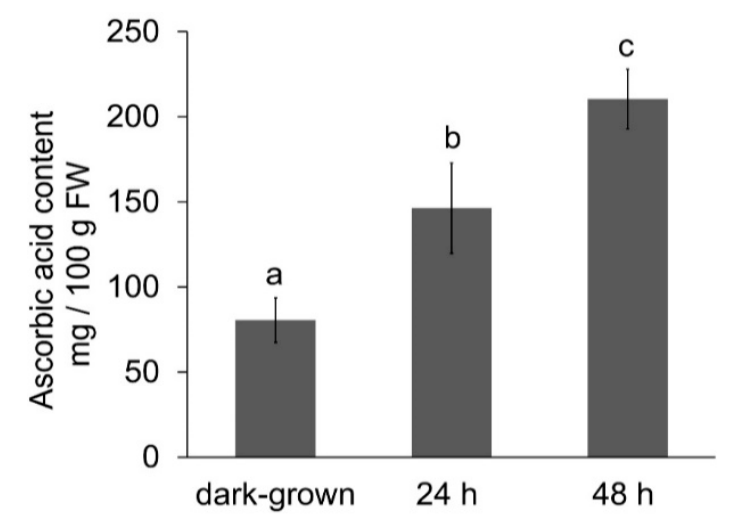

Figure 3. Ascorbic acid (AA) content in dark-grown chia microgreens and microgreens after exposure to light for 24 and $48 \mathrm{~h}$. Data represent mean values from three experiments with five replicates $(\mathrm{n}=15)$. The error bars show standard deviation (SD). Different letters signify values that are statistically different at $p \leq 0.05$ according to Fisher's LSD test.

$\mathrm{Lu}$ and Guo [11] obtained similar results in mung bean sprouts grown under different light regimes (24 and $12 \mathrm{~h}$ light and dark-grown), showing that the content of AA increased due to the longer exposure to illumination.

When raw seeds and sprouts, such as soybean, mung bean, cowpea, and buckwheat, were compared, studies found that the AA content was lower in raw seeds [7]. The germination process significantly increased AA content in various edible seeds and sprouts. It was suggested that an increase of AA content and its accumulation in sprouts is due to de novo synthesis [11]. Namely, the synthesis of AA depends on electron transport within the photosynthetic apparatus. Since AA also plays an important role in photoprotection, exposure of dark-grown chia microgreens triggered increased AA synthesis in order to prevent photodamage in etiolated plants and diminished the production of reactive oxygen species [46].

\subsection{Crystalline Cellulose Content}

Dietary fibers have a beneficial effect on the gastrointestinal system, and chia seeds are rich in dietary fibers [47]. Since cellulose presents one of the main components of dietary fibers, we investigated the effect of light on cellulose content in chia microgreens, considering that germination can impact dietary fiber depending on the germination time as well as plant species [48].

The cellulose content in dark-grown chia microgreens and microgreens $24 \mathrm{~h}$ after light exposure did not show significant differences. On the other hand, a significant decrease in cellulose content was observed in microgreens $48 \mathrm{~h}$ after exposure to light (Table 1 ).

The germination process tends to increase dietary fiber content in different plant species such as peas and amaranth, as well as others [49-51]. Gómez-Favela et al. [5] reported on lower dietary fiber content found in chia sprouts, suggesting that the synthesis of dietary fibers such as cellulose, hemicellulose, and pectin are much slower in comparison to other sprouts in particular growth conditions. 
Table 1. The crystalline cellulose content in dark-grown chia microgreens and microgreens 24 and $48 \mathrm{~h}$ after exposure to light.

\begin{tabular}{ccc}
\hline Dark-Grown & $\mathbf{2 4} \mathbf{h}$ & $\mathbf{4 8 ~ h}$ \\
\hline $0.656 \mathrm{a}$ & $0.657 \mathrm{a}$ & $0.317 \mathrm{~b}$ \\
\hline$( \pm 0.08)$ & $( \pm 0.09)$ & $( \pm 0.02)$ \\
\hline
\end{tabular}

Data represent mean values from three experiments with five replicates $(n=15)$ expressed as $\mu \mathrm{g}$ crystalline cellulose per mg of dry weight. Different letters signify values that are statistically different at $p \leq 0.05$ according to Fisher's LSD test. Values in the brackets represent \pm standard deviation (SD).

It is known that dark-grown microgreens have a characteristic pale phenotype with excessive shoot elongation compared to microgreens growing in normal light conditions. Therefore, more cellulose content could be found in such etiolated shoots [52]. In our study, a decline of cellulose content in microgreens, $48 \mathrm{~h}$ after exposure to light, could be due to the reprogramming of metabolic pathways and redirection of developmental processes in pathways that are light-dependent, such as photosynthesis and sugar synthesis, [53] as well as general plant elongation rather than cellulose synthesis.

\subsection{Effect of Illumination on Antioxidant Capacity}

It has been shown that the germination process promotes antioxidant capacity in different sprouts $[4,7,10,54]$. In our study, exposure to light generally increased the content of chlorophylls and carotenoids, total polyphenolics, and ascorbic acid, which are part of the plant's antioxidative system. Accordingly, it could be expected that the antioxidant capacity in the analyzed chia microgreens exposed to light will also be increased.

Light treatment caused an increase of total antioxidant capacity in chia microgreens measured by 1, 1-diphenyl-2-picrylhydrazyl scavenging radical (DPPH) assay. A significant difference was found between dark-grown and chia microgreens exposed to light. There were no differences in DPPH scavenging activity between microgreens exposed for 24 and $48 \mathrm{~h}$ (Figure $4 \mathrm{a}$ ).

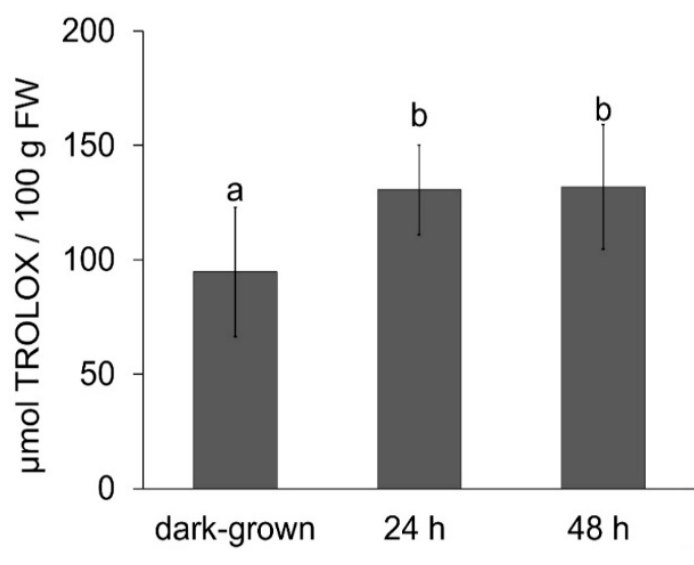

(a)

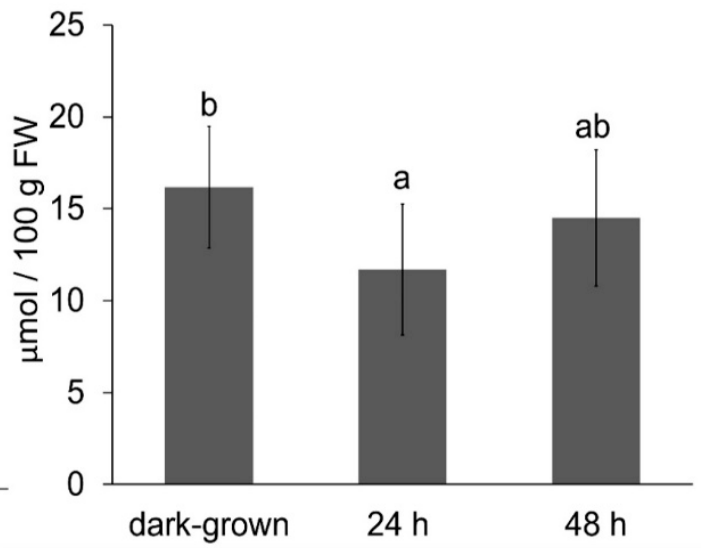

(b)

Figure 4. Antioxidant activity in dark-grown chia microgreens and microgreens after exposure to light for 24 and $48 \mathrm{~h}$ evaluated by DPPH scavenging activity (a) and FRAP assay (b). Data represent mean values from three experiments with five replicates $(n=15)$. The error bars show standard deviation (SD). Different letters signify values that are statistically different at $p \leq 0.05$ according to Fisher's LSD test.

In dark-grown chia microgreens, total antioxidative capacity measured by the FRAP assay was the highest (Figure $4 \mathrm{~b}$ ). When different light treatments were compared, similar values were observed in microgreens exposed to light for 24 and $48 \mathrm{~h}$, whilst a significant decrease was observed $24 \mathrm{~h}$ after exposure to light in comparison to dark-grown chia microgreens. 
The FRAP assay exhibited lower values in comparison with the DPPH assay. Other authors have also reported differences between obtained values when the two assays were used $[4,55]$. For instance, in 7-day-old chia sprouts exposed to $12 \mathrm{~h} / 12 \mathrm{~h}$ (light/dark) cycles, DPPH scavenging activity was lower in comparison to the FRAP assay [54]. The reason for such discrepancies might be due to differences in the chemistry and sensitivity of these two assays. In a recently published study by Mitrović et al. [38], the authors reported that the DPPH assay is more suitable than the FRAP assay for evaluating the antioxidant activity of chia. This suggests that the obtained values of these assays are impacted by the species, germination processes, and growth conditions, as well as temperature and duration of light exposure.

\subsection{Effect of Illumination on FTIR Spectra}

The FTIR spectra of the three chia samples under the study are depicted in Figure 5, and their main bands are summarized in Table 2. It can be observed that they are similar, in particular, the samples exposed to light for 24 and $48 \mathrm{~h}$.

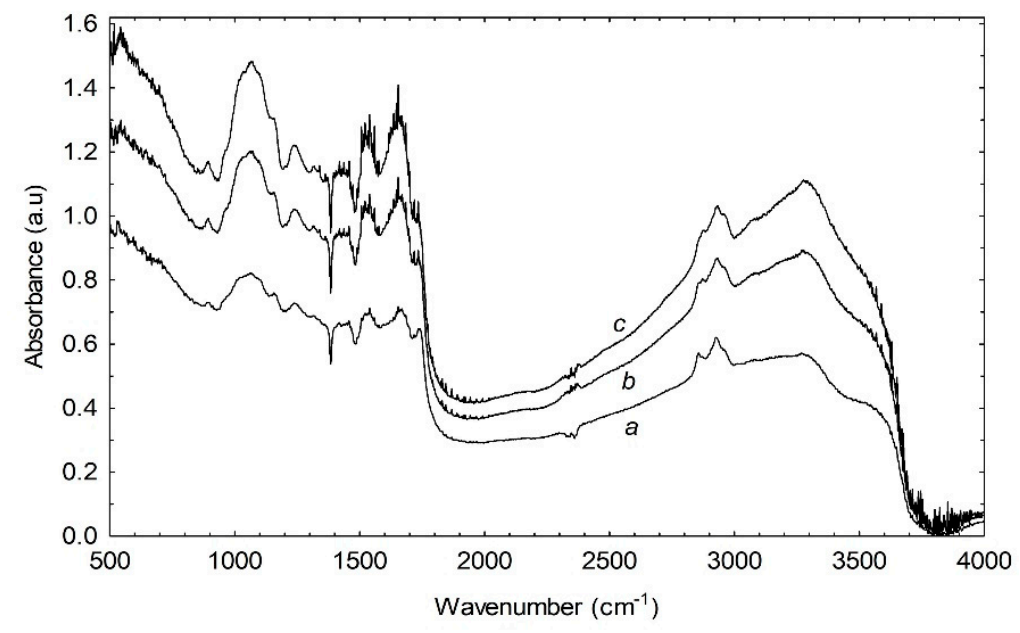

Figure 5. FTIR spectra of dark-grown (a) chia microgreens and microgreens after exposure to light for 24 (b) and 48 (c) h. FTIR spectrum was recorded by 20 co-added scans at a resolution of $2 \mathrm{~cm}^{-1}$ in the region of wave number $(\mathrm{WN}) 500$ to $4000 \mathrm{~cm}^{-1}$. The spectra were baseline-corrected.

Table 2. Main bands in the FTIR spectra and their assignments of dark-grown chia microgreens and microgreens after exposure to light for 24 and $48 \mathrm{~h}$.

\begin{tabular}{|c|c|c|c|c|}
\hline Peak No. & Assignments & $\begin{array}{c}\text { Dark-Grown } \\
\text { Wavenumber }\left(\mathrm{cm}^{-1}\right)\end{array}$ & $\begin{array}{c}24 \mathrm{~h} \\
\text { Wavenumber }\left(\mathrm{cm}^{-1}\right)\end{array}$ & $\begin{array}{c}48 \mathrm{~h} \\
\text { Wavenumber }\left(\mathrm{cm}^{-1}\right)\end{array}$ \\
\hline I & not assigned & 889.9 & 890 & 889 \\
\hline II & Polysaccharides & 1062 & 1062 & 1063 \\
\hline III & Amide III region & 1238 & 1239 & 1239 \\
\hline IV & Amide III region & 1457 & 1457 & 1457 \\
\hline $\mathrm{V}$ & Amide II region & 1540 & 1540 & 1540 \\
\hline VI & Amide I region & 1647 & 1647 & 1647 \\
\hline VII & Fat content & 2855 & disappeared & disappeared \\
\hline VIII & Fat content & 2926 & 2927 & 2925 \\
\hline IX & Protein content & 3269 & 3270 & 3271 \\
\hline
\end{tabular}

A large number of peaks appeared in the region from 1000 to $3000 \mathrm{~cm}^{-1}$, indicating that chia microgreens have a rich chemical composition (proteins, lipids, carbohydrates) [18]. More precisely, the band located around $3290 \mathrm{~cm}^{-1}$ represents $\mathrm{N}-\mathrm{H}$ stretching vibrations that are caused by proteins [20]. The bands between 2800 and $3000 \mathrm{~cm}^{-1}$ mainly represent $\mathrm{C}-\mathrm{H}$ stretching vibrations that are caused by lipids. The region between 1550 and $1700 \mathrm{~cm}^{-1}$ are protein absorption bands, including amide I and 
amide II. Additionally, the fingerprint region between 1000 and $1500 \mathrm{~cm}^{-1}$ is where amide II and the functional groups of nucleic acid and carbohydrates contribute to these absorption bands.

In comparison with the other two samples, the dark-grown chia sample showed negligible differences regarding the peak shifting in the region comprised between 1000 and $1700 \mathrm{~cm}^{-1}$. We observed two well-pronounced bands in dark-grown chia microgreens around 2855 and $2926 \mathrm{~cm}^{-1}$. Regarding the peak shifting, with the increment of light treatment, the band at about $2855 \mathrm{~cm}^{-1}$ (dark-grown microgreens) disappeared in illuminated microgreens (24 and $48 \mathrm{~h}$ ), while bands at $2926 \mathrm{~cm}^{-1}$ remain relatively stable in all chia samples.

Nine main bands were analyzed between 800 and $3500 \mathrm{~cm}^{-1}$ in the spectra of the three chia samples, and the band positions were relatively similar (with the exception of the band at $2855 \mathrm{~cm}^{-1}$ ) to each other, indicating that structure was sensitive to treatments in the region of fats, vax, and lipids after 24 and 48 h of exposure to light $[19,20]$.

\section{Conclusions}

Our findings show that growth conditions with the lower light intensity of $100 \mu \mathrm{mol}$ photons $\mathrm{m}^{-2} \mathrm{~s}^{-1}$ evoked a positive effect on total antioxidant capacity, synthesis of chlorophyll and carotenoids, total soluble phenolics, and ascorbic acid in dark-grown chia microgreens. Thus, the synthesis of bioactive compounds and the antioxidative potential of illuminated chia microgreens was improved. The DPPH assay was shown to be more sensitive in detecting antioxidative activity in comparison with FRAP. Therefore, we can conclude that chia microgreens could be considered a valuable supplement to the human diet, in addition to raw chia seeds and other popular microgreens. Present trends use different approaches in growing different sprouts and microgreens that are used for human consumption. Further investigations should be undertaken to reveal the best practices in growing chia microgreens, as well as the effect of light on the regulation of molecular mechanisms involved in the synthesis of bioactive compounds.

Author Contributions: Conceptualization, S.M. and L.B.; methodology, V.G., A.V., and M.V.; formal analysis, I.V., V.G., A.V., and M.V.; writing - original draft preparation, S.M. and L.B.; writing-review and editing, S.M., L.B., and V.C. All authors have read and agreed to the published version of the manuscript.

Funding: This research received no external funding.

Acknowledgments: The authors wish to thank Ksenija Doboš for valuable technical assistance.

Conflicts of Interest: The authors declare no conflict of interest.

\section{References}

1. Cahill, J.P. Ethnobotany of Chia, Salvia hispanica L. (Lamiaceae). Econ. Bot. 2003, 57, 604-618. [CrossRef]

2. Borneo, R.; Aguirre, A.; León, A.E. Chia (Salvia hispanica L) Gel Can Be Used as Egg or Oil Replacer in Cake Formulations. J. Am. Diet. Assoc. 2010, 110, 946-949. [CrossRef] [PubMed]

3. da Silva Marineli, R.; Moraes, É.A.; Lenquiste, S.A.; Godoy, A.T.; Eberlin, M.N.; Maróstica, M.R., Jr. Chemical characterization and antioxidant potential of Chilean chia seeds and oil (Salvia hispanica L.). LWT Food Sci. Technol. 2014, 59, 1304-1310. [CrossRef]

4. del Carmen Beltran-Orozco, M.; Martinez-Olguin, A.; del Carmen Robles-Ramirez, M. Changes in the Nutritional Composition and Antioxidant Capacity of Chia Seeds (Salvia hispanica L.) During Germination Process. Food Sci. Biotechnol. 2020, 29, 751-757. [CrossRef] [PubMed]

5. Gómez-Favela, M.A.; Gutiérrez-Dorado, R.; Cuevas-Rodríguez, E.; Canizález-Román, A.; León-Sicairos, C.D.R.; Milán-Carrillo, J.; Reyes-Moreno, C. Improvement of Chia Seeds with Antioxidant Activity, GABA, Essential Amino Acids, and Dietary Fiber by Controlled Germination Bioprocess. Plant Foods Hum. Nutr. 2017, 72, 345-352. [CrossRef]

6. Benincasa, P.; Falcinelli, B.; Lutts, S.; Stagnari, F.; Galieni, A. Sprouted Grains: A Comprehensive Review. Nutrients 2019, 11, 421. [CrossRef] 
7. Gan, R.-Y.; Lui, W.-Y.; Wu, K.; Chan, C.-L.; Dai, S.-H.; Sui, Z.-Q.; Corke, H. Bioactive compounds and bioactivities of germinated edible seeds and sprouts: An updated review. Trends Food Sci. Technol. 2017, 59, 1-14. [CrossRef]

8. Wang, H.; Gui, M.; Tian, X.; Xin, X.; Li, J. Effects of UV-B on vitamin C, phenolics, flavonoids and their related enzyme activities in mung bean sprouts (Vigna radiata). Int. J. Food Sci. Technol. 2017, 52, 827-833. [CrossRef]

9. Samuolienè, G.; Urbonavičiūtè, A.; Brazaitytè, A.; Šabajevienè, G.; Sakalauskaitè, J.; Duchovskis, P. The impact of LED illumination on antioxidant properties of sprouted seeds. Open Life Sci. 2011, 6, 68-74. [CrossRef]

10. Chen, C.-C.; Huang, M.Y.; Lin, K.H.; Wong, S.L.; Huang, W.D.; Yang, C.M. Effects of Light Quality on the Growth, Development and Metabolism of Rice Seedlings (Oryza sativa L.). Res. J. Biotechnol. 2014, 9, 15-24.

11. Lu, Y.; Guo, X. The Effect of Light in Vitamin C Metabolism Regulation and Accumulation in Mung Bean (Vigna radiata) Germination. Plant Foods Hum. Nutr. 2020, 75, 24-29. [CrossRef] [PubMed]

12. Ntagkas, N.; Woltering, E.J.; Marcelis, L.F. Light regulates ascorbate in plants: An integrated view on physiology and biochemistry. Environ. Exp. Bot. 2018, 147, 271-280. [CrossRef]

13. Bailly, C. Active oxygen species and antioxidants in seed biology. Seed Sci. Res. 2004, 14, 93-107. [CrossRef]

14. Sun, T.; Li, L. Toward the 'golden' era: The status in uncovering the regulatory control of carotenoid accumulation in plants. Plant Sci. 2020, 290, 110331. [CrossRef]

15. Rodríguez-Villalón, A.; Gas, E.; Rodríguez-Concepción, M. Colors in the Dark: A Model for the Regulation of Carotenoid Biosynthesis in Etioplasts. Plant Signal. Behav. 2009, 4, 965-967. [CrossRef]

16. Kyriacou, M.C.; De Pascale, S.; Kyratzis, A.; Rouphael, Y. Microgreens as a Component of Space Life Support Systems: A Cornucopia of Functional Food. Front. Plant Sci. 2017, 8, 1587. [CrossRef]

17. Baseri, M.K.; Baker, S. Identification of Cellular Components of Medicinal Plants Using Ftir. Rom. J. Biophys. 2011, 21, 277-284.

18. Carrión-Prieto, P.; Martín-Ramos, P.; Hernández-Navarro, S.; Silva-Castro, I.; Silva, M.R.; Martín-Gil, J. Vibrational Analysis and Thermal Behavior of Salvia hispanica, Nigella sativa and Papaver somniferum Seeds. Pharmacogn. J. 2017, 9, 157-162. [CrossRef]

19. Vargas, O.L.T.; Salcedo, A.J.G.; Calderón, H.A. Physical-chemical characterization of quinoa (Chenopodium quinoa Willd.), amaranth (Amaranthus caudatus L.), and chia (Salvia hispanica L.) flours and seeds. Acta Agron. 2018, 67, 215-222. [CrossRef]

20. Darwish, A.; Khalifa, R.E.; El Sohaimy, S.A. Functional Properties of Chia Seed Mucilage Supplemented In Low Fat Yoghurt. Alex. Sci. Exch. J. 2018, 39, 450-459. [CrossRef]

21. Lichtenthaler, H.K. [34] Chlorophylls and carotenoids: Pigments of photosynthetic biomembranes. Methods Enzymol. 1987, 148, 350-382.

22. Bradford, M.M. A rapid and sensitive method for the quantitation of microgram quantities of protein utilizing the principle of protein-dye binding. Anal. Biochem. 1976, 72, 248-254. [CrossRef]

23. Brand-Williams, W.; Cuvelier, M.; Berset, C. Use of a free radical method to evaluate antioxidant activity. LWT Food Sci. Technol. 1995, 28, 25-30. [CrossRef]

24. Bessey, O.A.; Lowry, O.H.; Brock, M.J. A method for the rapid determination of alkaline phosphates with five cubic millimeters of serum. J. Biol. Chem. 1946, 164, 321-329.

25. Updegraff, D.M. Semimicro determination of cellulose inbiological materials. Anal. Biochem. 1969, 32, $420-424$. [CrossRef]

26. Foster, C.E.; Martin, T.M.; Pauly, M. Comprehensive Compositional Analysis of Plant Cell Walls (Lignocellulosic Biomass) Part II: Carbohydrates. JoVE (J. Vis. Exp.) 2010, 37, e1837. [CrossRef]

27. de Paiva, E.P.; Torres, S.B.; Sá, F.V.; Nogueira, N.W.; Freitas, R.M.; Leite, M.D. Light regime and temperature on seed germination in Salvia hispanica L. Acta Sci. Agron. 2016, 38, 513-519. [CrossRef]

28. Solymosi, K.; Mysliwa-Kurdziel, B. Chlorophylls and their Derivatives Used in Food Industry and Medicine. Mini Rev. Med. Chem. 2017, 17, 1194-1222. [CrossRef]

29. Zepka, L.Q.; Jacob-Lopes, E.; Roca, M. Catabolism and bioactive properties of chlorophylls. Curr. Opin. Food Sci. 2019, 26, 94-100. [CrossRef]

30. Zheng, H.; You, Y.; Hua, M.; Wu, P.; Liu, Y.; Chen, Z.; Zhang, L.; Wei, H.; Li, Y.; Luo, M. Chlorophyllin Modulates Gut Microbiota and Inhibits Intestinal Inflammation to Ameliorate Hepatic Fibrosis in Mice. Front. Physiol. 2018, 9, 1671. [CrossRef] 
31. Honarvar, N.M.; Saedisomeolia, A.; Abdolahi, M.; Shayeganrad, A.; Sangsari, G.T.; Rad, B.H.; Muench, G. Molecular Anti-inflammatory Mechanisms of Retinoids and Carotenoids in Alzheimer's Disease: A Review of Current Evidence. J. Mol. Neurosci. 2016, 61, 289-304. [CrossRef] [PubMed]

32. Elvira-Torales, L.I.; García-Alonso, F.J.; Periago, M.J. Nutritional Importance of Carotenoids and Their Effect on Liver Health: A Review. Antioxidants 2019, 8, 229. [CrossRef] [PubMed]

33. Bahonar, A.; Saadatnia, M.; Khorvash, F.; Maracy, M.; Khosravi, M. Carotenoids as potential antioxidant agents in stroke prevention: A systematic review. Int. J. Prev. Med. 2017, 8. [CrossRef]

34. Edge, R.; Truscott, T.G. Singlet Oxygen and Free Radical Reactions of Retinoids and Carotenoids-A Review. Antioxidants 2018, 7, 5. [CrossRef] [PubMed]

35. Ilieva, I.; Ivanova, T.; Naydenov, Y.; Dandolov, I.; Stefanov, D. Plant experiments with light-emitting diode module in Svet space greenhouse. Adv. Space Res. 2010, 46, 840-845. [CrossRef]

36. Walters, R.G.; Shephard, F.; Rogers, J.J.; Rolfe, S.A.; Horton, P. Identification of Mutants of Arabidopsis Defective in Acclimation of Photosynthesis to the Light Environment1. Plant Physiol. 2003, 131, 472-481. [CrossRef]

37. Weiguo, F.; Pingping, L.; Yanyou, W.; Jianjian, T. Effects of different light intensities on anti-oxidative enzyme activity, quality and biomass in lettuce. Hortic. Sci. 2012, 39, 129-134. [CrossRef]

38. Mitrović, J.S.; Nikolić, N.; Karabegović, I.; Lazić, M.; Stojanović, G. Characterization of free and insoluble-bound phenolics of chia (Salvia hispanica L.) seeds. Nat. Prod. Res. 2020, 1-5. [CrossRef]

39. Paśko, P.; Barton, H.J.; Zagrodzki, P.; Gorinstein, S.; Fołta, M.; Zachwieja, Z. Anthocyanins, total polyphenols and antioxidant activity in amaranth and quinoa seeds and sprouts during their growth. Food Chem. 2009, 115, 994-998. [CrossRef]

40. Guzmán-Ortiz, F.A.; Martín-Martínez, E.S.; Valverde, M.E.; Rodríguez-Aza, Y.; Berríos, J.D.J.; Mora-Escobedo, R. Profile Analysis and Correlation across Phenolic Compounds, Isoflavones and Antioxidant Capacity during Germination of Soybeans (Glycine max L.). CyTA J. Food 2017, 15, 516-524. [CrossRef]

41. Wu, Z.; Song, L.; Feng, S.; Liu, Y.; He, G.; Yioe, Y.; Liu, S.; Huang, D.-J. Germination Dramatically Increases Isoflavonoid Content and Diversity in Chickpea (Cicer arietinum L.) Seeds. J. Agric. Food Chem. 2012, 60, 8606-8615. [CrossRef]

42. Xu, M.; Jin, Z.; Ohm, J.B.; Schwarz, P.; Rao, J.; Chen, B. Improvement of the Antioxidative Activity of Soluble Phenolic Compounds in Chickpea by Germination. J. Agric. Food Chem. 2018, 66, 6179-6187. [CrossRef]

43. Mastropasqua, L.; Dipierro, N.; Paciolla, C. Effects of Darkness and Light Spectra on Nutrients and Pigments in Radish, Soybean, Mung Bean and Pumpkin Sprouts. Antioxidants 2020, 9, 558. [CrossRef] [PubMed]

44. Smirnoff, N. Ascorbic Acid Metabolism and Functions: A Comparison of Plants and Mammals. Free Radic. Boil. Med. 2018, 122, 116-129. [CrossRef] [PubMed]

45. Dowdle, J.; Ishikawa, T.; Gatzek, S.; Rolinski, S.; Smirnoff, N. Two Genes in Arabidopsis Thaliana Encoding Gdp-L-Galactose Phosphorylase Are Required for Ascorbate Biosynthesis and Seedling Viability. Plant J. 2007, 52, 673-689. [CrossRef]

46. Talla, S.; Riazunnisa, K.; Padmavathi, L.; Sunil, B.; Rajsheel, P.; Raghavendra, A. Ascorbic Acid Is a Key Participant During the Interactions between Chloroplasts and Mitochondria to Optimize Photosynthesis and Protect against Photoinhibition. J. Biosci. 2011, 36, 163-173. [CrossRef] [PubMed]

47. Reyes-Caudillo, E.; Tecante, A.; Valdivia-López, M. Dietary fibre content and antioxidant activity of phenolic compounds present in Mexican chia (Salvia hispanica L.) seeds. Food Chem. 2008, 107, 656-663. [CrossRef]

48. Nelson, K.; Stojanovska, L.; Vasiljevic, T.; Mathai, M. Germinated grains: A superior whole grain functional food? Can. J. Physiol. Pharmacol. 2013, 91, 429-441. [CrossRef]

49. Martín-Cabrejas, M.A.; Ariza, N.; Esteban, R.M.; Mollá, E.; Waldron, K.; López-Andréu, F.J. Effect of Germination on the Carbohydrate Composition of the Dietary Fiber of Peas (Pisum sativum L.). J. Agric. Food Chem. 2003, 51, 1254-1259. [CrossRef] [PubMed]

50. Perales-Sánchez, J.X.K.; Reyes-Moreno, C.; Gómez-Favela, M.A.; Milán-Carrillo, J.; Cuevas-Rodríguez, E.; Valdez-Ortiz, A.; Gutiérrez-Dorado, R. Increasing the Antioxidant Activity, Total Phenolic and Flavonoid Contents by Optimizing the Germination Conditions of Amaranth Seeds. Plant Foods Hum. Nutr. 2014, 69, 196-202. [CrossRef] [PubMed]

51. Tiansawang, K.; Luangpituksa, P.; Varanyanond, W.; Hansawasdi, C. Gaba (Г-Aminobutyric Acid) Production, Antioxidant Activity in Some Germinated Dietary Seeds and the Effect of Cooking on Their Gaba Content. Food Sci. Technol. 2016, 36, 313-321. [CrossRef] 
52. Mølmann, J.A.B.; Johansen, T.J. Sprout Growth Inhibition and Photomorphogenic Development of Potato Seed Tubers (Solanum tuberosum L.) Under Different LED Light Colours. Potato Res. 2020, 63, 199-215.

53. Dong, J.; Terzaghi, W.B.; Deng, X.W.; Chen, H. Multiple Photomorphogenic Repressors Work in Concert to Regulate Arabidopsis Seedling Development. Plant Signal. Behav. 2015, 10, e1011934. [CrossRef] [PubMed]

54. Pająk, P.; Socha, R.; Broniek, J.; Królikowska, K.; Fortuna, T. Antioxidant Properties, Phenolic and Mineral Composition of Germinated Chia, Golden Flax, Evening Primrose, Phacelia and Fenugreek. Food Chem. 2019, 275, 69-76. [CrossRef]

55. Pellegrini, M.; Lucas-González, R.; Sayas-Barberá, E.; Fernández-López, J.; Pérez-Álvarez, J.A.; Viuda-Martos, M. Bioaccessibility of Phenolic Compounds and Antioxidant Capacity of Chia (Salvia hispanica L.) Seeds. Plant Foods Hum. Nutr. 2017, 73, 47-53. [CrossRef]

(C) 2020 by the authors. Licensee MDPI, Basel, Switzerland. This article is an open access article distributed under the terms and conditions of the Creative Commons Attribution (CC BY) license (http://creativecommons.org/licenses/by/4.0/). 